\title{
Primary cutaneous marginal zone B-cell lymphoma: a molecular and clinicopathological study of cases from Asia, Germany, and the United States
}

\author{
Hisashi Takino ${ }^{1}$, Chunmei $\mathrm{Li}^{1}$, Sindy $\mathrm{Hu}^{2}$, Tseng-Tong $\mathrm{Kuo}^{3}$, Eva Geissinger ${ }^{4}$, \\ Hans Konrad Muller-Hermelink ${ }^{4}$, Bong $\mathrm{Kim}^{5}$, Steven H Swerdlow ${ }^{5}$ and Hiroshi Inagaki ${ }^{1}$ \\ ${ }^{1}$ Department of Pathology, Nagoya City University Graduate School of Medical Sciences, Nagoya, Japan; \\ ${ }^{2}$ Department of Dermatology, Chang Gung Memorial Hospital, Chang Gung University College of Medicine, \\ Taoyuan, Taiwan; ${ }^{3}$ Department of Pathology, Chang Gung Memorial Hospital, Chang Gung University College \\ of Medicine, Taoyuan, Taiwan; ${ }^{4}$ Institute of Pathology, University of Wuerzburg, Wuerzburg, Germany and \\ ${ }^{5}$ Department of Pathology, University of Pittsburgh, School of Medicine, Pittsburgh, PA, USA
}

\begin{abstract}
Primary cutaneous marginal zone B-cell lymphoma is considered the cutaneous counterpart of extranodal marginal zone B-cell lymphoma of mucosa-associated lymphoid tissue. Although its molecular pathogenesis is currently unknown, an etiological link with Borrelia burgdorferi infection has been identified in European, but not in American or Asian cases. To better understand the pathogenesis and the geographical differences of cutaneous marginal zone B-cell lymphoma, 60 cases from the East Asia, Germany, and the United States at their initial presentation were subjected to the following analyses; (1) clinicopathological comparison between the geographical regions, (2) detection of $B$. burgdorferi DNA, (3) detection of the API2-MALT1 fusion transcript, a gene alteration specific to mucosa-associated lymphoid tissue lymphoma, and (4) inactivation of tumor suppressor genes (death-associated protein kinase (DAPK), p16 ${ }^{I N K 4 a}, p 14^{A R F}, M G M T, T I M P 3, C D H 1$, and RARB) by hypermethylation of the CpG islands. Cases from the three geographical regions showed similar clinicopathological features. However, moderate/marked tissue eosinophilia was found in 9/25 Asian cases, but only $1 / 23$ German cases $(P=0.011)$ and $0 / 12$ American cases $(P=0.015)$. All 60 cases were negative for either Borrelia DNA or API2-MALT1 fusion. Tumors from the three regions were highly methylated for DAPK (38-50\% of the cases, mean $43 \%$ ) and $p 16^{\prime N K 4 a}(42-70 \%$, mean $49 \%)$, and the positivities were significantly higher than those of nonneoplastic skin $(8 \%, P=0.0010$ and $14 \%, P=0.0032$, respectively). Methylation of these genes had no significant association with progressive features of the tumor. Primary cutaneous marginal zone B-cell lymphomas from the three geographical regions have common clinicopathological features, however, moderate/marked tissue eosinophilia is a feature found almost exclusively in Asian cases. Borrelia infection and API2-MALT1 fusion are not significant in this tumor. Methylation of DAPK and $p 16^{\text {NKKa }}$ genes is a frequent event in this lymphoma at its initial presentation, but may not be associated with tumor progression.
\end{abstract}

Modern Pathology (2008) 21, 1517-1526; doi:10.1038/modpathol.2008.159; published online 26 September 2008

Keywords: primary cutaneous marginal zone B-cell lymphoma; molecular and clinicopathological study; international study

Primary cutaneous marginal zone B-cell lymphoma is now considered a distinct entity in the World Health Organization (WHO)-European Organization Research and Treatment of Cancer (EORTC) classi-

Correspondence: Dr H Inagaki, MD, Department of Pathology, Nagoya City University Graduate School of Medical Sciences, 1 Kawasumi, Mizuho-ku, Nagoya, 467-8601, Japan.

E-mail: hinagaki@med.nagoya-cu.ac.jp

Received 16 May 2008; revised 18 August 2008; accepted 19

August 2008; published online 26 September 2008 fication of cutaneous lymphomas., ${ }^{1,2}$ This tumor is histologically characterized by small $\mathrm{B}$ cells including marginal zone (centrocyte-like), monocytoid, and plasmacytoid lymphocytes, and plasma cells, and is considered part of the broad group of extranodal marginal zone B-cell lymphomas commonly involving mucosa-associated lymphoid tissue (MALT). This lymphoma is rare, often affects adults aged more than 40 years of age with no clear gender preponderance, and has a favorable prognosis. ${ }^{1-3}$ 
The etiology of cutaneous marginal zone B-cell lymphoma has not been well clarified. Evidence suggesting a link between this lymphoma and Borrelia burgdorferi infection has been reported from many European countries including Germany, and penicillin therapy may cure $B$. burgdorferiassociated cases. ${ }^{4-7}$ However, this association has not been evident in the United States or Asia. ${ }^{8,9}$ API2-MALT1 fusion, resulting from $\mathrm{t}(11 ; 18)$ (q21;q21) is specific to MALT lymphoma, and has been found in $10-20 \%$ of gastric cases and in up to $50 \%$ of pulmonary cases, but is rare in autoimmuneassociated cases. ${ }^{10}$ This gene alteration has been reported in $0-7.8 \%$ of cutaneous marginal zone B-cell lymphomas, ${ }^{9,11-16}$ but overall its frequency is not clear.

As the skin is one of the most important immune defense systems, cutaneous lymphoproliferative disorders are considered to be associated with environmental or geographical factors, especially in marginal zone B-cell lymphoma, which shows a close association with chronic inflammation. The present international study with cutaneous marginal zone B-cell lymphoma from East Asia, Germany, and the United States was designed to investigate any possible geographical differences among these cases, and to detect underlying biologic or genetic abnormalities. We analyzed the clinicopathological features of 60 cases of primary cutaneous marginal zone B-cell lymphoma, and searched for $B$. burgdorferi infection and API2-MALT1 fusion involvement. In addition, we studied inactivation of tumor suppressor genes by hypermethylation of the CpG islands, which is one of the important steps in the development of clinically overt tumors including malignant lymphoma.

\section{Materials and methods}

\section{Case Selection}

Asian cases of primary cutaneous marginal zone B-cell lymphoma were retrieved from the files of Department of Pathology, Chang Gung University, Taiwan, and Department of Pathology, Nagoya City University, Japan. Cases from Germany and the United States were retrieved from the files of the Department of Pathology, University of Wuerzburg, and the Department of Pathology, University of Pittsburgh, respectively. A total of 105 cases suspected of cutaneous marginal zone B-cell lymphoma were reviewed by hematopathologists. Of them, 55 cases were excluded either because they did not fulfill the criteria of the criteria for a cutaneous marginal zone B-cell lymphoma according to the criteria of WHO-EORTC classification for cutaneous lymphomas, ${ }^{1,2}$ they were recurrences, or they lacked demonstrable monoclonality either based on immunoglobulin light chain restriction or IGH gene rearrangement. ${ }^{9}$ Clinical data (age, sex, primary site, treatment, response, and follow-up) were obtained.
Clinical data concerning gross appearance and number of lesions (solitary or multiple) were available in Asian cases. In all cases, there was no history of extracutaneous lymphoma, either previous or concurrent, and no evidence of extracutaneous lymphoma for 6 months after the appearance of the cutaneous lesion.

All cases were within the morphological boundaries of primary cutaneous marginal zone B-cell lymphoma, and exhibited the following immunophenotype: $\operatorname{CD} 20(+), \quad \operatorname{CD} 79 \mathrm{a}(+), \quad \operatorname{CD} 3(-)$, CD45RO(-), CD5(-), CD10(-), CD23(-), BCL2(+), BCL6(-), and cyclin D1(-). The following pathological/phenotypic factors were analyzed in the cases from three geographical regions: proliferation pattern, increased lymphoid follicles, marked plasma cells, increased large cells, tissue eosinophilia, and nuclear BCL10 expression. When most lymphoma cells showed intense nuclear BCL10 expression, the case was considered as positive. Cases were considered to have increased large cells when more than $5 \%$ and less than $10 \%$ large cells were observed without solid or sheet-like proliferations. ${ }^{17}$ Tissue eosinophilia was semi-quantified into three groups: absent or mild, less than 50 eosinophils/10 high power fields (HPFs); moderate, 50-200 eosinophils/10 HPFs; and marked, more than 200 eosinophils/10 HPFs. Local ethical guidelines were followed for the use of archival materials for research, and such use was approved by the ethics committees of the authors' institutions where required. As a control, 29 nonneoplastic skin biopsies were obtained from Japanese patients. All specimens were fixed in formalin, and embedded in paraffin. Some of the tumors from Asian cases in this series were included in our previous study. ${ }^{9}$

\section{Extraction of Genomic DNA and Total RNA}

Genomic DNA and total RNA were extracted from paraffin sections in digestion buffer containing proteinase $\mathrm{K}$ as previously described. ${ }^{18}$ For lymphoma cases, only lymphomatous areas were scraped with examination of tissue sections under a dissecting microscope, using a serial $\mathrm{H} \& \mathrm{E}$ section as a guide. For control skin, only the dermal layer was scraped. We confirmed that all cases had a sufficient quality of DNA and RNA by polymerase chain reaction (PCR) for $\beta$-globin gene and reverse transcription (RT)-PCR for $\beta$-actin mRNA, respectively.

\section{PCR Detection of Borrelia DNA}

As reported previously, we performed PCR using consensus primers for $B$. burgdorferi $h b b$ gene, which encodes a protein of histone-like family. The PCR product is expected to be $184 \mathrm{bp}$ in length, and well suited to DNA extraction from paraffin tissue materials. ${ }^{9}$ This PCR assay should cover 
39 Borrelia strains. DNA extracted from heat-treated B. burgdorferi (Kirkegaad and Perry Lab, Gathersburg, MD, USA) was used as a positive control. The sequence analysis of the PCR product of the positive control showed $98 \%$ homology with the reference $B$. burgdorferi strain, B31. ${ }^{9}$ Normal human DNA extracted from various paraffinembedded materials, including the skin, spleen, and lymph nodes, yielded no positive bands in this PCR assay.

\section{Multiplex RT-PCR for the API2-MALT1 Fusion Transcript}

The API2-MALT1 fusion transcript was detected according to the method we previously described. ${ }^{19}$ All eight variant transcripts known to date can be detected with this assay. Briefly, total RNA was subjected to first-round multiplex one-tube RTPCR, then to second-round nested multiplex PCRs (three in parallel). This RT-PCR assay using paraffin tissues is highly efficient and has $94 \%$ of the sensitivity and $100 \%$ of the specificity obtained with RT-PCR using frozen materials. ${ }^{20}$

\section{Methylation-Specific PCR}

As described elsewhere, DNA from the specimens was first subjected to bisulfite treatment. ${ }^{21}$ Denatured DNA was modified by reaction with sodium bisulfite under conditions that convert all unmethylated cytosine residues to uracil by deamination. Modified DNA was purified, and modification was completed by $\mathrm{NaOH}$ treatment, followed by ethanol precipitation. Bisulfite-modified DNA was then subjected to PCR amplification using primers designed to anneal specifically to the methylated and unmethylated DNA within a given gene. In this study, we analyzed the hypermethylation status in the promotor CpG islands of following seven tumor suppressor genes: death-associated protein kinase (DAPK), p16 $6^{I N K 4 a}$ (p16), p14 ${ }^{A R F}$ (p14), O-6-methylguanine-DNA methytransferase (MGMT), tissue inhibitor of metalloproteinase 3 (TIMP3), E-cadherin (CDH1), and retinoic acid receptor- $\beta$ (RARB). The primer sequences are shown in Supplementary data 1. PCR was performed for 35 cycles, and the annealing temperature ranged from 55 to $63^{\circ} \mathrm{C}$ depending on the primer pairs used.

\section{Statistical Analysis}

Statistical comparisons were performed using Fischer's exact test and $\chi^{2}$-test. To identify the parameters significantly associated with an overall survival, the statistical difference was estimated using the log-rank and Wilcoxon tests. All analyses were two tailed. A value of $P<0.05$ for each test was regarded as statistically significant. All of the analyses were performed using the statistical package JMP (SAS Institute Inc., Cary, NC, USA).

\section{Results}

\section{Clinicopathological Findings}

All 60 cases of primary cutaneous marginal zone B-cell lymphoma occurred in adults (mean age of 56 years, median 57 , range $26-87$ ), with no differences in age between patients from the three regions (Asia, Germany, and the United States; Table 1). No gender preponderance was noted. In 25 Asian cases, tumors were found in the head and neck, trunk, and upper extremities in $10(40 \%), 8$ (32\%), and 7 (28\%) cases, respectively. Tumors were frequently found on the trunk $(9 / 23,39 \%)$ and upper extremities $(6 / 23,26 \%)$ in German cases, and mostly on the trunk $(9 / 12$, $75 \%$ ) in the cases from the United States. The cases from the three geographical regions showed similar histological findings (Figure 1a-d). The dermis showed a nonepidermotropic diffuse and nodular proliferation of small- to medium-sized lymphoid cells with reactive lymphoid follicles. The lymphoid cells had centrocyte-like or monocytoid appearance with pale cytoplasm, slightly irregular nuclei, and inconspicuous nucleoli. Marked plasmacytic differentiation was found in $19 / 60(32 \%)$ cases, and increased large cells in 12/60 $(20 \%)$ cases. Moderate or marked tissue eosinophilia in the tumor tissue was detected frequently in $9(36 \%)$ of 25 Asian cases (Figure 1e), but in only $1(4 \%)$ of 23 German, and none of 12 American cases $(P=0.011$, Asia vs Germany; $P=0.015$, Asia vs the United States; Table 1). There were no significant differences between Asian cases with and without tissue eosinophilia with regard to the following clinicopathological factors: age, sex, primary site, gross appearance, solitary or multiple, proliferation pattern, increased lymphoid follicles, marked plasma cells, and nuclear BCL10 expression. Nuclear BCL10 expression was detected in 30$40 \%$ of the cases, and there were no regional differences (Table 1).

Follow-up data were retrieved from 27 cases (Table 2). The follow-up period ranged from 7 to 180 months (median 36 months, mean 57 months). After a variety of treatments including surgical excision, topical steroid, psoralen and ultraviolet A phototherapy, and chemotherapy, 17 patients achieved a complete remission and 3 patients showed a partial remission, whereas 2 patients showed no change, and 3 showed progressive disease. Response to treatment was unknown in two cases. Of 17 patients with a complete remission, 5 relapsed. One case, which was observed with no treatment, showed spontaneous regression and no recurrence during the follow-up (Case 2, Table 2). Another case, which had no treatment, showed partial tumor regression but with persistent tumor 60 months after its initial 
Table 1 Comparison of clinical and histological findings between primary cutaneous marginal zone B-cell lymphoma cases from Asia, Germany, and the United States

\begin{tabular}{|c|c|c|c|c|c|c|c|}
\hline \multirow[t]{2}{*}{ Factor } & \multirow{2}{*}{$\begin{array}{l}\text { All regions } \\
(\mathrm{n}=60)\end{array}$} & \multirow{2}{*}{$\begin{array}{c}\text { Asia } \\
(\mathrm{n}=25)\end{array}$} & \multirow{2}{*}{$\begin{array}{c}\text { Germany } \\
(\mathrm{n}=23)\end{array}$} & \multirow{2}{*}{$\begin{array}{c}U S A \\
(\mathrm{n}=12)\end{array}$} & \multicolumn{3}{|c|}{$\mathrm{P}$} \\
\hline & & & & & Asia vs Germany & Asia vs USA & Germany vs USA \\
\hline \multicolumn{8}{|l|}{ Clinical findings } \\
\hline \multicolumn{8}{|l|}{ Age (years) } \\
\hline$>60$ & 26 & 7 & 12 & 7 & NS & NS & NS \\
\hline$<60$ & 34 & 18 & 11 & 5 & & & \\
\hline \multicolumn{8}{|l|}{ Sex } \\
\hline Male & 31 & 12 & 15 & 4 & NS & NS & NS \\
\hline Female & 29 & 13 & 8 & 8 & & & \\
\hline \multicolumn{8}{|l|}{ Primary site $(n=56)$} \\
\hline Head and neck & 15 & 10 & 2 & 3 & NS & 0.028 & NS \\
\hline Trunk & 26 & 8 & 9 & 9 & & & \\
\hline Upper extremities & 13 & 7 & 6 & 0 & & & \\
\hline Others & 2 & 0 & 2 & 0 & & & \\
\hline \multicolumn{8}{|l|}{ Histological findings } \\
\hline \multicolumn{8}{|l|}{ Proliferation pattern } \\
\hline Nodular & 25 & 14 & 7 & 4 & NS & NS & NS \\
\hline Nodular and diffuse & 35 & 11 & 16 & 8 & & & \\
\hline \multicolumn{8}{|c|}{ Increased lymphoid follicles } \\
\hline Yes & 32 & 17 & 11 & 4 & NS & NS & NS \\
\hline No & 28 & 8 & 12 & 8 & & & \\
\hline \multicolumn{8}{|l|}{ Marked plasma cells } \\
\hline Yes & 19 & 5 & 9 & 5 & NS & NS & NS \\
\hline No & 41 & 20 & 14 & 7 & & & \\
\hline \multicolumn{8}{|l|}{ Increased large cells } \\
\hline Yes & 12 & 4 & 6 & 2 & NS & NS & NS \\
\hline No & 48 & 21 & 17 & 10 & & & \\
\hline \multicolumn{8}{|l|}{ Tissue eosinophilia } \\
\hline Moderate or marked & 10 & 9 & 1 & 0 & 0.011 & 0.015 & NS \\
\hline Absent or mild & 50 & 16 & 22 & 12 & & & \\
\hline \multicolumn{8}{|l|}{ Nuclear BCL10 } \\
\hline Positive & 21 & 10 & 7 & 4 & NS & NS & NS \\
\hline Negative & 39 & 15 & 16 & 8 & & & \\
\hline
\end{tabular}

NS, not significant.

presentation (Case 13, Table 2). None of the patients died of the lymphoma.

\section{Borrelia DNA and the API2-MALT1 Fusion Transcript}

Satisfactory preservation of DNA was verified in all 60 cases by successful amplification of the $\beta$-globin DNA fragments. Borrelia DNA was not found in any case from Asia, Germany, or the United States (Figure 2). This negative result was confirmed by at least two separate experiments whereas the positive control for Borrelia DNA constantly showed a distinct PCR band. The API2-MALT1 fusion transcript was examined using multiplex RT-PCR. A sufficient quality of RNA was preserved in all 60 cases as evidenced by amplification of reference $\beta$-actin mRNA. No case showed the fusion transcript, a finding that was confirmed by repeat assays (Figure 3). Positive controls yielded definite bands.

\section{Gene Methylation Status}

As shown in Figure 4, the promoter regions of seven tumor suppressor genes (DAPK, p16, p14, MGMT, TIMP3, $C D H 1$, and $R A R B$ ) were analyzed for gene methylation in 89 skin biopsies (60 tumor cases and 29 cases of nonneoplastic skin). As summarized in Figure 5, methylation status was successfully evaluated for the former five genes in more than $88 \%$ of the cases, although the evaluation was somewhat lower in the latter two with mean detection rates of 77 and $73 \%$, respectively. DAPK gene methylation was detected in 9/24 (38\%), 6/12 (50\%), and 10/22 $(45 \%)$ of tumor cases from Asia, Germany, and the United States, respectively (differences not significant), with an average of $25 / 58(43 \%)$ cases. DAPK 
was methylated in 2/26 (8\%) nonneoplastic control cases. DAPK methylation ratios for each geographical region and that of total cases were significantly higher than that of nonneoplastic skin (Table 3). p16
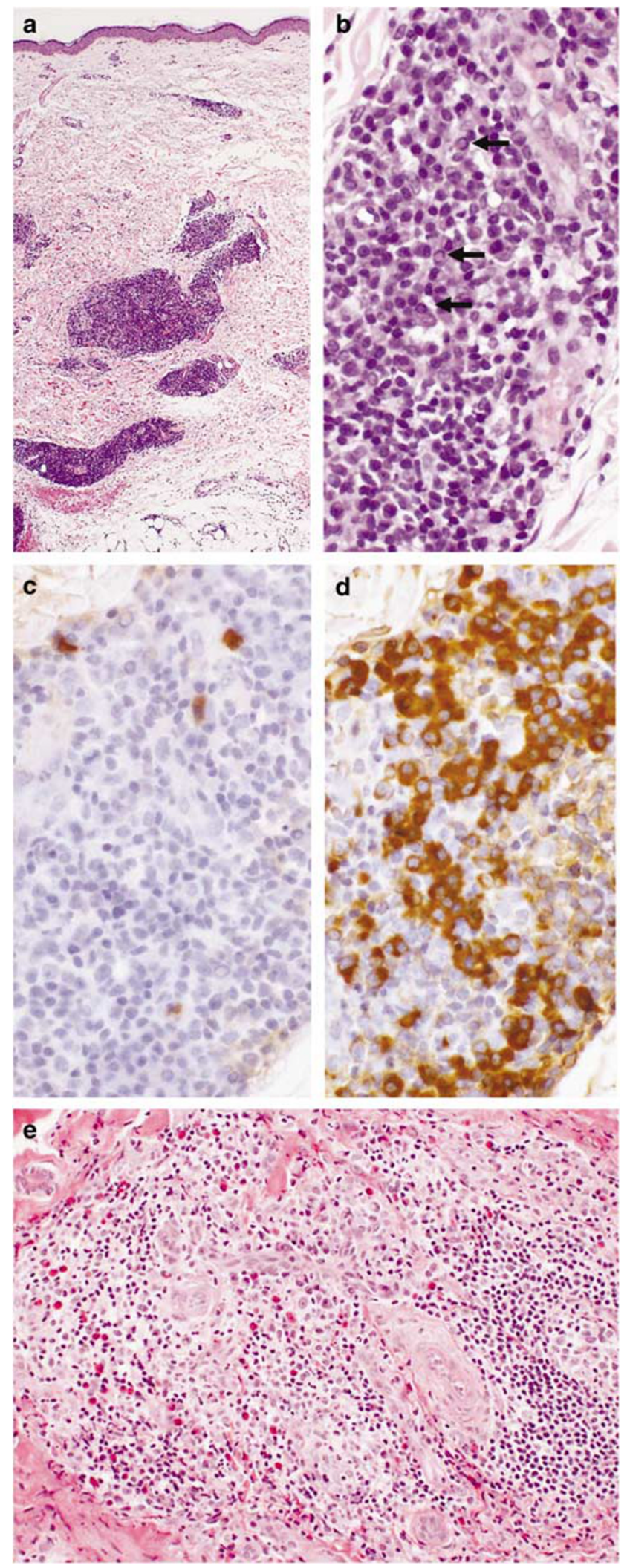

gene methylation was frequently detected in cutaneous marginal zone B-cell lymphoma cases, and the detection was similar between the three regions (42, 47, and $60 \%$ in Asia, Germany, and the United States, respectively) with an average of $47 \%(25 / 53$ cases). $p 16$ gene methylation in tumor cases was significantly higher than control cases $(4 / 28,14 \%$; Table 4). The other five genes ( $p 14, M G M T$, TIMP3, $C D H 1$, and $R A R B$ ) were differentially methylated in $47,7,15,31$, and $14 \%$ of the tumor cases, respectively. These methylation ratios were not statistically different from those of the control skin.

When association of gene hypermethylation with clinicopathological factors was analyzed, none of the following factors showed a statistically significant association with the methylation status of either $D A P K$ or $p 16$ gene (Table 4): age, sex, primary site, gross appearance, proliferation pattern, increased lymphoid follicles, marked plasmacytic differentiation, increased large-cell element, tissue eosinophilia, and BCL10 expression. Prognostic analysis showed that $p 16$ and $D A P K$ hypermethylation had no impact on the disease-free survival of the patients (data not shown).

\section{Discussion}

In the present study, we examined 60 cases of primary cutaneous marginal zone B-cell lymphoma from Asia, Germany, and the United States. These cases generally showed clinicopathological features similar to those that have been described. However, a predominant localization to the trunk and upper extremities $^{1,2}$ was not shown in this study. The prognosis of the patients was excellent with no tumor-related deaths recorded in this study. However, the therapeutic response was not very satisfactory. A complete remission was achieved in 17 $(68 \%)$ of 25 cases with known responses to treatment. Among these 17 patients, 5 cases showed tumor recurrence but without any lymphomarelated deaths. In total, 13/25 (52\%) patients were alive with disease at the last follow-up. This finding confirmed previous observations that primary cutaneous marginal zone B-cell lymphoma is an indolent tumor, but often shows resistance to or recurrence after treatment of the tumor., ${ }^{3,22}$

Of note, we found that moderate or marked tissue eosinophilia was observed frequently in Asian

\footnotetext{
Figure 1 Histopathological findings in primary cutaneous marginal zone B-cell lymphoma. (a) Nodular proliferation of dense lymphoid cells mainly in the dermis. $\mathrm{H} \& \mathrm{E}$ staining, original magnification $\times 40$. (b) Lymphoid and plasmacytic cells with frequent intranuclear pseudoinclusions (Dutcher bodies, arrows), H\&E staining, original magnification $\times 400$. (c, d) Tumor cells showing immunoglobulin light chain restriction (c, $\kappa$-type; d, $\lambda$-type), hematoxylin counterstain, original magnification $\times 400$. (e) A representative case of tissue eosinophilia (an Asian case) This case is graded as 'moderate'. H\&E staining, original magnification $\times 200$.
} 
Table 2 Treatment, response, and follow-up of primary cutaneous marginal zone B-cell lymphoma

\begin{tabular}{|c|c|c|c|c|c|c|c|}
\hline Case & Region & Age & Sex & Treatment & Response & Follow-up (months) & Comments \\
\hline 1 & Asia & 71 & $\mathrm{M}$ & Surgical excision & $\mathrm{PD}$ & 12 & Recurrence in other sites \\
\hline 2 & Asia & 27 & $\mathrm{~F}$ & None & CR (spontaneous) & 24 & No recurrence \\
\hline 3 & Asia & 49 & $\mathrm{M}$ & Surgical excision & CR & 24 & No recurrence \\
\hline 4 & Asia & 70 & $\mathrm{~F}$ & Topical steroid & NC & 24 & Tumor persisting \\
\hline 5 & Asia & 65 & $\mathrm{M}$ & Surgical excision & CR & 32 & No recurrence \\
\hline 6 & Asia & 57 & $\mathrm{~F}$ & Chemotherapy & $\mathrm{CR}$ & 36 & No recurrence \\
\hline 7 & Asia & 44 & M & Surgical excision & CR & 168 & Recurrence in other sites \\
\hline 8 & Asia & 69 & $\mathrm{M}$ & Topical steroid & PD & 96 & Recurrence in other sites \\
\hline 9 & Asia & 40 & $\mathrm{~F}$ & Surgical excision & CR & 36 & No recurrence \\
\hline 10 & Asia & 54 & $\mathrm{~F}$ & None & PD & 8 & Tumor persisting \\
\hline 11 & Germany & 75 & $\mathrm{~F}$ & Unknown & PR & 120 & Tumor persisting \\
\hline 12 & Germany & 52 & $\mathrm{~F}$ & Surgical excision & CR & 36 & No recurrence \\
\hline 13 & Germany & 65 & $\mathrm{~F}$ & None & PR (spontaneous) & 60 & Tumor persisting \\
\hline 14 & Germany & 45 & $\mathrm{~F}$ & Radiation & CR & 48 & No recurrence \\
\hline 15 & Germany & 50 & $\mathrm{~F}$ & Radiation & CR & 48 & No recurrence \\
\hline 16 & Germany & 40 & M & Unknown & CR & 7 & Recurrence \\
\hline 17 & Germany & 35 & $\mathrm{~F}$ & Surgical excision and radiation & CR & 180 & Recurrence \\
\hline 18 & Germany & 78 & $\mathrm{M}$ & Chemotherapy & PR & 60 & Tumor persisting \\
\hline 19 & Germany & 70 & $\mathrm{M}$ & Radiation and topical steroid & CR & 72 & Recurrence \\
\hline 20 & Germany & 74 & $\mathrm{M}$ & Radiation & CR & 96 & No recurrence \\
\hline 21 & USA & 58 & M & Surgical excision & CR & 53 & No recurrence \\
\hline 22 & USA & 68 & $\mathrm{~F}$ & Unknown & Unknown & 96 & Alive and well \\
\hline 23 & USA & 56 & $\mathrm{M}$ & Surgical excision & CR & 32 & No recurrence \\
\hline 24 & USA & 72 & $\mathrm{~F}$ & Unknown & NC & 9 & Tumor persisting \\
\hline 25 & USA & 77 & $\mathrm{M}$ & Unknown & Unknown & 108 & Alive and well \\
\hline 26 & USA & 53 & $\mathrm{~F}$ & Radiation & CR & 33 & No recurrence \\
\hline 27 & USA & 67 & $\mathrm{~F}$ & Surgical excision & CR & 19 & No recurrence \\
\hline
\end{tabular}

CR, complete remission; PR, partial remission; NC, no change; PD progressive disease; M, male; F, female.

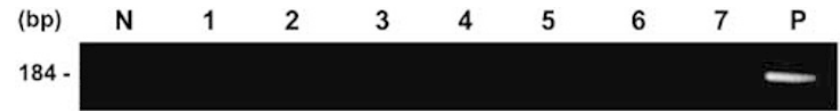

Figure 2 Detection of Borrelia DNA by PCR amplifying a fragment of conserved $h b b$ gene. $\mathrm{N}$, negative control; P, positive control; lanes 1-7, tumor cases showing no detectable PCR products. bp, base pair.

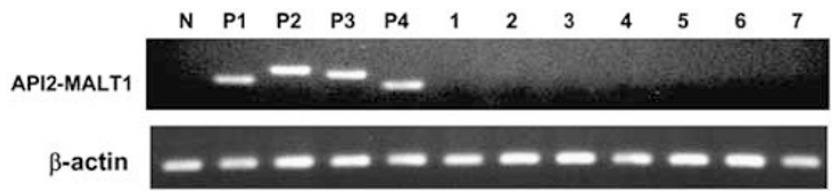

Figure 3 Detection of API2-MALT1 fusion transcript by multiplex RT-PCR (second PCR-B). N, negative control; P1-P4, four variants of API2-MALT1 fusion used as positive controls (note that PCR bands vary in size); lanes 1-7, tumor cases negative for the fusion transcript.

cases, which has not been noted before. In contrast, this finding was almost absent in Germany and the United States cases. Tissue eosinophilia has been reported in 4 of 15 American cases, ${ }^{23}$ although the degree of eosinophilia was not specified. In malignant lymphoma, tissue eosinophilia is often associated in Hodgkin's lymphoma and T-cell lymphoma. ${ }^{24,25}$ This phenomenon may be associated with production of certain cytokines by the tumor cells, and may have a prognostic significance. ${ }^{26}$ In B-cell lymphomas, however, tissue eosinophilia is

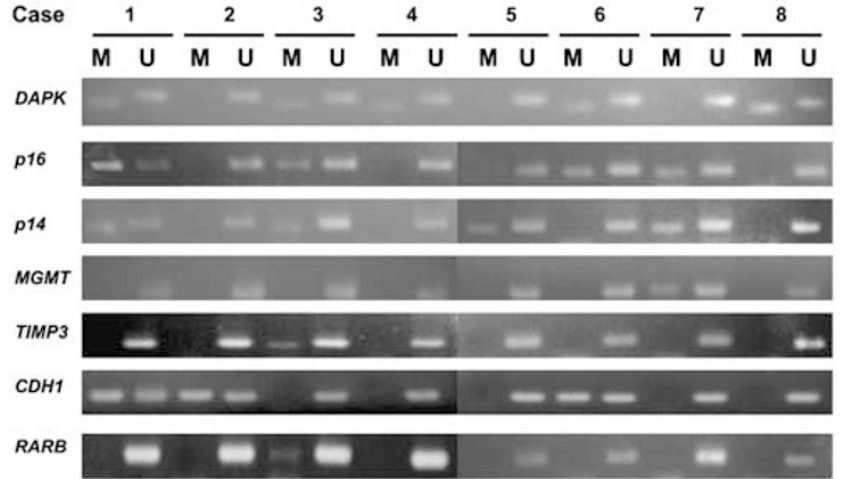

Figure 4 Methylation-specific PCR for methylation status of seven tumor suppressor genes, DAPK, p16, p14, MGMT, TIMP3, $C D H 1$, and $R A R B$. Cases 1-8, tumor cases; M, methylated; U, unmethylated. The PCR product sizes are shown in Supplementary data 1.

rare, and its significance is unknown. ${ }^{27}$ In the present series, we found no significant differences in the clinicopathological features between those with and without tissue eosinophilia. We speculate that frequent tissue eosinophilia may be associated with ethnic or geographical factors. One such example is Kimura's disease, which is characterized by marked eosinophilia. ${ }^{28,29}$ This benign disorder, involving the skin as well as the lymph nodes, is known to be comparatively frequent in Asian countries. 


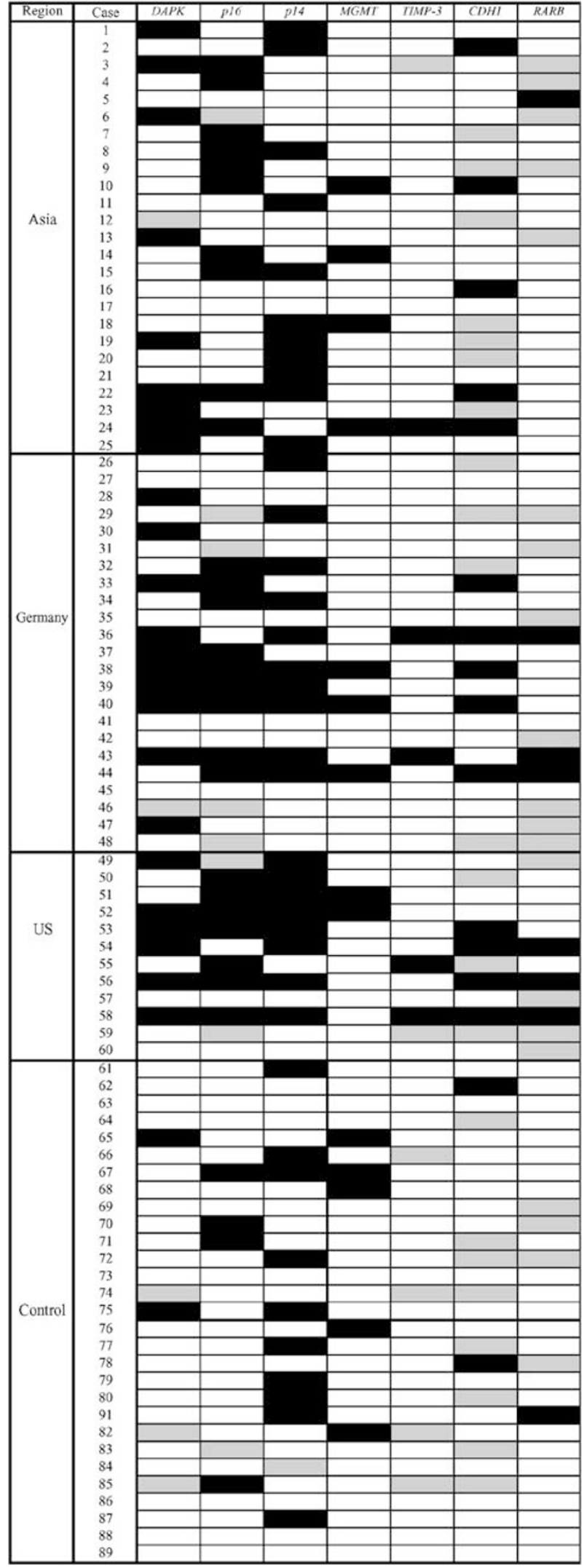

Figure 5 Methylation profile of seven tumor suppressor genes in 60 cases of primary cutaneous marginal zone B-cell lymphoma and 29 cases of the control skin. Filled boxes indicate methylated sites, open boxes indicate unmethylated sites, and gray boxes indicate that the methylation status is not determined.
Table 3 Methylation of $D A P K$ and $p 16$ genes between geographical regions

\begin{tabular}{lrcrc}
\hline \multirow{2}{*}{ Case } & \multicolumn{4}{c}{ Gene methylation (\%) } \\
\cline { 2 - 5 } & DAPK & $\mathrm{P}^{\mathrm{a}}$ & $\mathrm{p} 16$ & $\mathrm{P}^{\mathrm{a}}$ \\
\hline Asia & $9 / 24(38)$ & 0.016 & $10 / 24(42)$ & 0.033 \\
Germany & $10 / 22(45)$ & 0.0059 & $9 / 19(47)$ & 0.020 \\
USA & $6 / 12(50)$ & 0.0066 & $7 / 10(70)$ & 0.0022 \\
All regions & $25 / 58(43)$ & 0.0010 & $26 / 53(49)$ & 0.0032 \\
Control & $2 / 26(8)$ & & $4 / 28(14)$ & \\
\hline
\end{tabular}

${ }^{\mathrm{a} C o m p a r i s o n}$ with control.

A subset of primary cutaneous marginal zone B-cell lymphoma cases has been associated with $B$. burgdorferi, however, there appears to be geographic variation. Borrelia infection has been documented serologically, and Borrelia-specific DNA has been detected by PCR and Southern blot analysis. ${ }^{4-7}$ In addition, antibiotic therapy has been effective in some cases that were positive for $B$. burgdorferi. ${ }^{6,7}$ Interestingly, this association has been reported mainly from Europe, but rarely from the United States. ${ }^{8,30}$ We previously reported that such an association is also rare in Asian cases. ${ }^{9}$ In this international study including cases from Asia, Germany, and the United States, we found that none of the cases was positive for $B$. burgdorferi DNA. Although this negative PCR result does not exclude the possibility of a link between the tumor and $B$. burgdorferi infection, the microorganism is not significant in the development or pathogenesis of the cases of primary cutaneous marginal zone Bcell lymphoma.

The molecular pathogenesis of cutaneous marginal zone B-cell lymphoma is poorly understood with the translocations associated with other MALT lymphomas reportedly found in few cases. Streubel et al ${ }^{12}$ reported API2-MALT1 translocation in 4 of 51 cases, but others, including the cases reported here, did not detect any cases with this abnormality. ${ }^{9,11,13-16}$ The IGH-MALT1 translocation has been reported in $7 / 51$ cases $^{12}$ and $3 / 12$ cases. $^{15}$ However, it was absent in several other studies. ${ }^{13,14}$ The explanation for these variable results remains unknown. In MALT lymphomas, an association between nuclear BCL10 expression and the presence of API2-MALT1 fusion has been suggested. ${ }^{10,31}$ However, such an association was not evident in our series where frequent nuclear BCL10 expression in tumor cells was shown in the absence of API2-MALT1 fusion, as has been reported previously., ${ }^{9,16}$ In cutaneous marginal zone B-cell lymphoma, nuclear BCL10 expression has not been associated with BCL10 gene mutation $^{9}$ or other MALT1 gene translocations. ${ }^{16}$ These molecular data indicate that some other mechanisms exist for nuclear BCL10 expression in cutaneous marginal zone B-cell lymphoma.

Inactivation of tumor suppressor genes by hypermethylation of the $\mathrm{CpG}$ islands is one of the 
Table $4 D A P K$ and $p 16$ gene methylation and clinicopathological factors

\begin{tabular}{|c|c|c|c|c|c|c|}
\hline \multirow[t]{2}{*}{ Factor } & \multicolumn{3}{|c|}{ DAPK gene } & \multicolumn{3}{|c|}{ p16 gene } \\
\hline & Methylated & Unmethylated & $\mathrm{P}$ & Methylated & Unmethylated & $\mathrm{P}$ \\
\hline \multicolumn{7}{|l|}{ Clinical } \\
\hline \multicolumn{7}{|l|}{ Age (years) } \\
\hline$>60$ & 8 & 17 & NS & 12 & 10 & NS \\
\hline$<60$ & 17 & 16 & & 13 & 18 & \\
\hline \multicolumn{7}{|l|}{ Sex } \\
\hline Male & 12 & 18 & NS & 17 & 11 & NS \\
\hline Female & 13 & 15 & & 8 & 17 & \\
\hline \multicolumn{7}{|l|}{ Primary site } \\
\hline Head and neck & 5 & 10 & NS & 5 & 8 & NS \\
\hline Others & 20 & 23 & & 20 & 20 & \\
\hline \multicolumn{7}{|l|}{ Gross appearance $^{\mathrm{a}}$} \\
\hline Plaque or papule & 3 & 4 & NS & 2 & 5 & NS \\
\hline Nodule & 6 & 11 & & 8 & 9 & \\
\hline \multicolumn{7}{|l|}{ No. of lesions ${ }^{a}$} \\
\hline Solitary & 3 & 11 & NS & 5 & 9 & NS \\
\hline Multiple & 5 & 4 & & 5 & 4 & \\
\hline \multicolumn{7}{|l|}{ Histological } \\
\hline \multicolumn{7}{|l|}{ Proliferation pattern } \\
\hline Nodular & 8 & 15 & NS & 9 & 12 & NS \\
\hline Nodular and diffuse & 17 & 18 & & 17 & 15 & \\
\hline \multicolumn{7}{|c|}{ Increased lymphoid follicles } \\
\hline Yes & 15 & 17 & NS & 14 & 16 & NS \\
\hline No & 10 & 16 & & 12 & 11 & \\
\hline \multicolumn{7}{|l|}{ Marked plasma cells } \\
\hline Yes & 8 & 9 & NS & 9 & 7 & NS \\
\hline No & 17 & 24 & & 17 & 20 & \\
\hline \multicolumn{7}{|l|}{ Increased large cells } \\
\hline Yes & 6 & 6 & NS & 6 & 5 & NS \\
\hline No & 19 & 27 & & 20 & 22 & \\
\hline \multicolumn{7}{|l|}{ Tissue eosiniophilia } \\
\hline Absent or mild & 22 & 26 & NS & 22 & 22 & NS \\
\hline Moderate or marked & 3 & 7 & & 4 & 5 & \\
\hline \multicolumn{7}{|l|}{ Nuclear BCL10 } \\
\hline Positive & 9 & 11 & NS & 11 & 8 & NS \\
\hline Negative & 16 & 22 & & 15 & 19 & \\
\hline
\end{tabular}

NS, not significant.

${ }^{\mathrm{a}}$ Data from Asian cases.

important processes in the development of clinically overt tumors. To the best of our knowledge, this epigenetic abnormality has not been studied in primary cutaneous marginal zone B-cell lymphoma. We therefore analyzed methylation of seven tumor suppressor genes, and found that DAPK and $p 16$ genes were highly methylated in tumor cases whereas nonneoplastic skin tissues (from Asian individuals) were rarely methylated. A similar low methylation of the two genes in nonneoplastic skin has been reported from the United States. ${ }^{32}$

DAPK is a novel calcium/calmodulin-dependent and cytoskeletal-associated serine/threonine kinase with death-inducing functions. ${ }^{33,34}$ The DAPK gene was initially isolated as a positive mediator of apoptosis induced by interferon- $\gamma$. Overexpression of DAPK in tumor cells led to cell death in the absence of any external stimuli. Recent studies showed that this molecule also participates in tumor necrosis factor- $\alpha$ and Fas-induced apoptosis. ${ }^{35,36}$ The $p 16$ gene encodes for nuclear protein that can block cell-cycle progression from the $G_{1}$ to the $S$ phase by effectively inhibiting the kinase activity of CDK4/6, thereby exerting a negative control on cell proliferation. ${ }^{37-39}$ Loss of p16 expression gives a remarkable growth advantage in cells. These observations highlight a potential role of $D A P K$ and $p 16$ as tumor suppressor genes. We showed that both DAPK 
and $p 16$ genes were frequently methylated in tumor cases at their initial presentation (approximately $45 \%$ of the cases) and that these epigenetic alterations had no impact on clinicopathological and prognostic features of this lymphoma. These findings suggest that methylation of these genes is a molecular event that may contribute more to the development of the tumor than to its progression. In other B-cell malignancies, DAPK and p16 gene methylation has been associated with tumor progression. ${ }^{4-42}$ However, recent studies have shown that methylation of these genes may be an early event in lymphomagenesis: $D A P K$ and $p 16$ gene methylation is frequently found in premalignant and low-grade lymphoid disorders, not associated with tumor progression, and their methylation status is maintained in higher-grade or advanced lymphoid neoplasms. ${ }^{4-48}$ In line with these findings, methylation of DAPK and p16 is a common, early epigenetic phenomenon that allows tumor cells to promote cellcycle progression and escape the normal apoptosis of a non-antigen-stimulated expanded B-cell population. Unlike base substitutions or gene deletions, changes in DNA methylation are potentially reversible. A hypomethylating agent, 5-aza-2'-deoxycytidine (decitabine) has been clinically useful in hematopoietic malignancies. ${ }^{49,50}$ The role of the agent in the tumor therapy remains to be determined or will have to be the subject of future studies.

In summary, we showed primary cutaneous marginal zone B-cell lymphomas from three geographical regions have common clinicopathological features as have been previously described. However, moderate or marked tissue eosinophilia was significantly frequent in the Asian cases. Borrelia infection and API2-MALT12 fusion, both of which have been implicated in the development of this tumor, were not detected in our series. Finally, we showed that methylation of DAPK and $p 16$ genes was frequent in primary cutaneous marginal zone B-cell lymphoma cases at their initial presentation, and had no impact on progressive features of the tumor cases.

\section{Acknowledgement}

This work was supported in part by a Grant-in-Aid for Scientific Research (C) from Japan Society for the Promotion of Science.

\section{Disclosure/conflict of interest}

All the authors declared no competing interests.

\section{References}

1 Willemze R, Jaffe ES, Burg G, et al. WHO-EORTC classification for cutaneous lymphomas. Blood 2005;105:3768-3785.
2 Kempf W, Burg G, Ralfkiaer E, et al. Cutaneous marginal zone B-cell lymphoma. In: LeBoit PE, Burg G, Weedon D, Sarasin A (eds). World Health Organization Classification of Tumours. Pathology and Genetics. Skin tumours. IARC Press: Lyon, 2006, pp 194-195.

3 Cho-Vega JH, Vega F, Rassidakis G, et al. Primary cutaneous marginal zone B-cell lymphoma. Am J Clin Pathol 2006;125:38-49.

4 Goodlad JR, Davidson MM, Hollowood K, et al. Primary cutaneous B-cell lymphoma and Borrelia burgdorferi infection in patients from the Highlands of Scotland. Am J Surg Pathol 2000;24:1279-1285.

5 Cerroni L, Zöchling N, Pütz B, et al. Infection by Borrelia burgdorferi and cutaneous B-cell lymphoma. J Cutan Pathol 1997;24:457-461.

6 Kutting B, Bonsmann G, Metze D, et al. Borrelia burgdorferi-associated primary cutaneous B cell lymphoma: complete clearing of skin lesions after antibiotic pulse therapy or intralesional injection of interferon alfa-2a. J Am Acad Dermatol 1997;36: 311-314.

7 Roggero E, Zucca E, Mainetti C, et al. Eradication of Borrelia burgdorferi infection in primary marginal zone B-cell lymphoma of the skin. Hum Pathol 2000;31: 263-268.

8 Wood GS, Kamath NV, Guitart J, et al. Absence of Borrelia burgdorferi DNA in cutaneous B-cell lymphomas from the United States. J Cutan Pathol 2001; 28:502-507.

9 Li C, Inagaki H, Kuo TT, et al. Primary cutaneous marginal zone B-cell lymphoma: a molecular and clinicopathologic study of 24 Asian cases. Am J Surg Pathol 2003;27:1061-1069.

10 Inagaki H. Mucosa-associated lymphoid tissue lymphoma: molecular pathogenesis and clinicopathological significance. Pathol Int 2007;57:474-484.

11 Grønbaek K, Ralfkiaer E, Kalla J, et al. Infrequent somatic Fas mutations but no evidence of Bcl10 mutations or $\mathrm{t}(11 ; 18)$ in primary cutaneous MALTtype lymphoma. J Pathol 2003;201:134-140.

12 Streubel B, Simonitsch-Klupp I, Müllauer L, et al. Variable frequencies of MALT lymphoma-associated genetic aberrations in MALT lymphomas of different sites. Leukemia 2004;18:1722-1726.

13 de la Fouchardiere A, Gazzo S, Balme B, et al. Cytogenetic and molecular analysis of 12 cases of primary cutaneous marginal zone lymphomas. Am J Dermatopathol 2006;28:287-292.

14 Wongchaowart NT, Kim B, Hsi ED, et al. $\mathrm{t}(14 ; 18)(\mathrm{q} 32 ; \mathrm{q} 21)$ involving IGH and MALT1 is uncommon in cutaneous MALT lymphomas and primary cutaneous diffuse large B-cell lymphomas. J Cutan Pathol 2006;33:286-292.

15 Schreuder MI, Hoefnagel JJ, Jansen PM, et al. FISH analysis of MALT lymphoma-specific translocations and aneuploidy in primary cutaneous marginal zone lymphoma. J Pathol 2005;205:302-310.

16 Gallardo F, Bellosillo B, Espinet B, et al. Aberrant nuclear BCL10 expression and lack of $\mathrm{t}(11 ; 18)(\mathrm{q} 21 ; \mathrm{q} 21)$ in primary cutaneous marginal zone B-cell lymphoma. Hum Pathol 2006;37:867-873.

17 Inagaki $\mathrm{H}$, Nakamura $\mathrm{T}$, Li C, et al. Gastric MALT lymphomas are divided into three groups based on responsiveness to Helicobacter pylori eradication and detection of API2-MALT1 fusion. Am J Surg Pathol 2004;28:1560-1567. 
18 Inagaki $\mathrm{H}$, Chan $\mathrm{JK}, \mathrm{Ng} \mathrm{JW}$, et al. Primary thymic extranodal marginal-zone B-cell lymphoma of mucosaassociated lymphoid tissue type exhibits distinctive clinicopathological and molecular features. Am J Pathol 2002;160:1435-1443.

19 Inagaki H, Okabe M, Seto M, et al. API2-MALT1 fusion transcripts involved in mucosa-associated lymphoid tissue lymphoma: multiplex RT-PCR detection using formalin-fixed paraffin-embedded specimens. Am J Pathol 2001;158:699-706.

20 Okabe M, Inagaki H, Ohshima K, et al. API2-MALT1 fusion defines a distinctive clinicopathologic subtype in pulmonary extranodal marginal zone B-cell lymphoma of mucosa-associated lymphoid tissue. Am J Pathol 2003;162:1113-1122.

21 Herman JG, Graff JR, Myöhänen S, et al. Methylationspecific PCR: a novel PCR assay for methylation status of CpG islands. Proc Natl Acad Sci USA 1996;93: 9821-9826.

22 Hoefnagel JJ, Vermeer MH, Jansen PM, et al. Primary cutaneous marginal zone B-cell lymphoma: clinical and therapeutic features in 50 cases. Arch Dermatol 2005;141:1139-1145.

23 Baldassano MF, Bailey EM, Ferry JA, et al. Cutaneous lymphoid hyperplasia and cutaneous marginal zone lymphoma: comparison of morphologic and immunophenotypic features. Am J Surg Pathol 1999;23:88-96.

24 Asadullah K, Döcke WD, Volk HD, et al. Cytokines and cutaneous T-cell lymphomas. Exp Dermatol 1998;7:314-320.

25 Roufosse F, Cogan E, Goldman M. Lymphocytic variant hypereosinophilic syndromes. Immunol Allergy Clin North Am 2007;27:389-413.

26 von Wasielewski R, Seth S, Franklin J, et al. Tissue eosinophilia correlates strongly with poor prognosis in nodular sclerosing Hodgkin's disease, allowing for known prognostic factors. Blood 2000;1595:1207-1213.

27 Navarro-Román L, Medeiros LJ, Kingma DW, et al. Malignant lymphomas of B-cell lineage with marked tissue eosinophilia. A report of five cases. Am J Surg Pathol 1994;18:347-356.

28 Kuo TT, Shih LY, Chan HL. Kimura's disease. Involvement of regional lymph nodes and distinction from angiolymphoid hyperplasia with eosinophilia. Am J Surg Pathol 1988;12:843-854.

29 Abuel-Haija M, Hurford MT. Kimura disease. Arch Pathol Lab Med 2007;131:650-651.

30 Bogle MA, Riddle CC, Triana EM, et al. Primary cutaneous B-cell lymphoma. J Am Acad Dermatol 2005;53:479-484.

31 Liu H, Ye H, Dogan A, et al. T(11;18)(q21;q21) is associated with advanced mucosa-associated lymphoid tissue lymphoma that expresses nuclear BCL10. Blood 2001;98:1182-1187.

32 Tyler LN, Ai L, Zuo C, et al. Analysis of promoter hypermethylation of death-associated protein kinase and p16 tumor suppressor genes in actinic keratoses and squamous cell carcinomas of the skin. Mod Pathol 2003;16:660-664.

33 Deiss LP, Feinstein E, Berissi H, et al. Identification of a novel serine/threonine kinase and a novel $15-\mathrm{kD}$ protein as potential mediators of the gamma interferon-induced cell death. Genes Dev 1995;9:15-30.
34 Cohen O, Feinstein E, Kimchi A. DAP-kinase is a Ca2+/ calmodulin-dependent, cytoskeletal-associated protein kinase, with cell death-inducing functions that depend on its catalytic activity. EMBO J 1997;16:998-1008.

35 Cohen O, Inbal B, Kissil JL, et al. DAP-kinase participates in TNF-alpha- and Fas-induced apoptosis and its function requires the death domain. J Cell Biol 1999;146:141-148.

36 Inbal B, Cohen O, Polak-Charcon S, et al. DAP kinase links the control of apoptosis to metastasis. Nature 1997;390:180-184.

37 Serrano M, Hannon GJ, Beach D. A new regulatory motif in cell-cycle control causing specific inhibition of cyclin D/CDK4. Nature 1993;366:704-707.

38 Lukas J, Parry D, Aagaard L, et al. Retinoblastomaprotein-dependent cell-cycle inhibition by the tumour suppressor p16. Nature 1995;375:503-506.

39 Kamb A, Gruis NA, Weaver-Feldhaus J, et al. A cell cycle regulator potentially involved in genesis of many tumor types. Science 1994;264:436-440.

40 Pinyol M, Cobo F, Bea S, et al. p16 (INK4a) gene inactivation by deletions, mutations, and hypermethylation is associated with transformed and aggressive variants of non-Hodgkin's lymphomas. Blood 1998;91:2977-2984.

41 Villuendas R, Sanchez-Beato M, Martinez JC, et al. Loss of p16/INK4A protein expression in non-Hodgkin's lymphomas is a frequent finding associated with tumor progression. Am J Pathol 1998;153:887-897.

42 Mateos MV, Garcia-Sanz R, Lopez-Perez R, et al. Methylation is an inactivating mechanism of the $p 16$ gene in multiple myeloma associated with high plasma cell proliferation and short survival. Br J Haematol 2002;118:1034-1040.

43 Gonzalez M, Mateos MV, Garcia-Sanz R, et al. De novo methylation of tumor suppressor gene $p 16 / I N K 4 a$ is a frequent finding in multiple myeloma patients at diagnosis. Leukemia 2000;14:183-187.

44 Guillerm G, Gyan E, Wolowiec D, et al. p16/INK4a and $p 15 / I N K 4 b$ gene methylation in plasma cells from monoclonal gammopathy of undetermined significance. Blood 2001;98:244-246.

45 Nakatsuka S, Takakuwa T, Tomita Y, et al. Role of hypermethylation of DAP-kinase CpG island in the development of thyroid lymphoma. Lab Invest 2000;80:1651-1655.

46 Katzenellenbogen RA, Baylin SB, Herman JG. Hypermethylation of the DAP-kinase CpG island is a common alteration in B-cell malignancies. Blood 1999;93:4347-4353.

47 Rossi D, Capello D, Gloghini A, et al. Aberrant promoter methylation of multiple genes throughout the clinico-pathologic spectrum of B-cell neoplasia. Haematologica 2004;89:154-164.

48 Takino H, Okabe M, Li C, et al. p16/INK4a gene methylation is a frequent finding in pulmonary MALT lymphomas at diagnosis. Mod Pathol 2005;18:1187-1192.

49 Momparler RL. Pharmacology of 5-aza-2'-deoxycytidine (decitabine). Semin Hematol 2005;42:S9-S16.

50 Jabbour E, Issa JP, Garcia-Manero G, et al. Evolution of decitabine development: accomplishments, ongoing investigations, and future strategies. Cancer 2008; 112:2341-2351.

Supplementary Information accompanies the paper on Modern Pathology website (http://www.nature.com/ modpathol) 